\title{
REVIEWS
}

\section{Pelican in tire Wilderness. By F. Fraser Darling. George Allen and Unwin, Ltd., 25s.}

What is the countryside of America really like? We are so accustomed to thinking of the United States as the fountain head of prosperity, as a land flowing with milk and honey, that Fraser Darling's book must come as a shock to most of us. It is true that he visited America as an ecologist, presumably both for his own enlightenment and as an adviser and so must have concentrated on those places where man's destruction has been worst and where the greatest effort to repair his damage was being made. Nevertheless we have here a frightening picture of the effects of land misuse and of the unthinking destruction of wild life, not only on animals but on the land itself. Fraser Darling reminds us of the results of killing of predators on the Kaibab plateau, well described some years ago by Gilbert T. Pearson. There, following Theodore Roosevelt's policy of absolute protection for deer, combined with destruction of puma and wolf, overgrazing created a desert and countless deer died in misery of starvation.

A somewhat similar policy is still in vogue in places, where not only is the prairie marmot trapped as a destroyer of the cattle range but, at the same time, the coyote which feeds on him is poisoned. Do not we in Britain likewise wage war on rats and mice and, at the same time, on stoats and weasels ?

It is a comfort to those who care about wild life for its own sake to feel that scientific opinion is more and more turning towards the view that the best land use from man's own point of view is often to leave the land to its own vegetation and wild animals.

When a rodent population has reached plague proportions, its natural enemies cannot control it, but, as Fraser Darling shows, where range is not heavily over-grazed, predators are effective. In other words, it is always the same cry-"If you upset the balance of nature, Beware".

This book is by no means the gloomy story which the above alone might lead you to expect. You go by land, sea and air to very many of the American states, including Alaska and on a visit to Mexico. You are introduced to scientists and many lesser folk engaged in conservation and in such a personal way that you must feel you get to know each one individually. In fact my own preference is for a slightly less personal approach, 
with concentration more on a man's work; but the personal approach of this book is very effective.

Fraser Darling has neither written merely a traveller's tale nor a text book on conservation; yet he has not fallen between the two. He has given us a very interesting travel story and told us enough about conservation to make us want to know what it really means and to try to discover how it can be brought about in face of our world's ever increasing population.

C. L. B.

Wild Life of tile World. Advisory Editor, Dr. Maunice Burton. Odham's Press, Ltd., London. 384 pp., over 200 illustrations. $13 s .6 d$.

A pretentious title indeed which requires explanation, for this handy, inexpensive volume is primarily concerned with mammals, to which ten of its fifteen chapters are devoted; four of the others deal with birds; and the last, intriguingly styled "Backwater of Evolution", touches briefly on reptiles and amphibians. Compiled under the expert guidance of Dr. Burton, who also contributes three of its chapters, one knows it is bound to be good. Other well-known zoologists and field naturalists are responsible for the remainder. It is written in simple language and the arrangement is sensible, while it will be as interesting and enjoyable to the general public as valuable to the student. But, one may well be excused for asking the question how yet another book on wild life is warranted when in recent years so many have been published. The answer is that this is something refreshingly new which graphically brings up-to-date our knowledge of mammals-and to a lesser extent of birds-for as in all fields of research much that is novel and strange is constantly being discovered. Constituting a veritable pocket encyclopedia, it is a fascinating compendium of the attributes and mode of life of the creatures with which it deals.

One must congratulate unreservedly all those who have participated in the production of so comprehensive a reference work, and one marvels at their skill in compressing so much valuable knowledge into such a limited space. The greatest difficulty must have been in deciding what to omit and there is little doubt that precious little which is pertinent or essential has been left out.

Eleven separate authorities are bound to differ considerably in style, yet an impressive standard of uniformity has been achieved. The main inconsistency is in the use of scientific names 